\title{
DUKUNGAN PENGEMBANGAN KARIR DAN PEMBERDAYAAN OLEH KEPALA SEKOLAH SERTA KONTRIBUSNYA TERHADAP KEPUASAN
}

\author{
KERJA GURU
}

\author{
Umi Jumroh ${ }^{1}$, Ipong Dekawati2 \\ 1,2Program Pascasarjana Universitas Wiralodra \\ 1umijumroh0@gmail.com, 2ipongdekawati@unwir.ac.id
}

\begin{abstract}
In general, teachers work to get satisfaction in carrying out their work. Satisfaction at work encourages the emergence of enthusiasm in work so that it tends to perform well. Many factors affect job satisfaction, including career development support and empowerment by the principal. The focus of the research is on how much the contribution of career development support and empowerment by the principal to teacher job satisfaction. The research method used is descriptive and verification methods, with data collection techniques using a Likert scale questionnaire, to the teacher. Processing of research results using regression analysis techniques. The significance test uses the F-test. The results showed that: (1) There was a positive and significant contribution of career development support to teacher job satisfaction. (2) There is a positive and significant contribution of empowerment by the principal to job satisfaction. (3) There is a positive and significant contribution to the support of career development and empowerment by the principal simultaneously to teacher job satisfaction. Considering that job satisfaction is very important in order to increase work motivation and school productivity, teachers as the most members of the education unit should be given even greater opportunities to grow followed by adequate funding assistance so that their careers develop more in the hope that teachers feel more satisfied at work. It is recommended to give more responsibility to the teacher so that the teacher unconsciously enters the empowerment process. Teachers should be alternately assigned to manage various activities with the authority to make decisions with the permission of the school principal. It is hoped that the teacher will develop his insight and confidence, which in turn can increase the level of satisfaction at work.
\end{abstract}

Keyword : Career Development, Teacher Empowerment, Job Satisfaction

\begin{abstract}
ABSTRAK
Pada umumnya guru bekerja untuk mendapatkan kepuasan dalam melaksanakan pekerjaannya. Kepuasan dalam bekerja mendorong munculnya semangat dalam bekerja sehingga cenderung kinerjanya bagus. Banyak faktor yang mempengaruhi kepuasan kerja, termasuk dukungan pengembangan karir dan pemberdayaan oleh kepala sekolah. Fokus penelitian pada seberapa besar kontribusi dukungan pengembangan karir dan pemberdayaan oleh kepala sekolah tersebut terhadap kepuasan kerja guru. Metode penelitian yang digunakan adalah metode deskriptif
\end{abstract}


dan verifikatif, dengan teknik pengumpulan data menggunakan angket skala Likert, terhadap guru. Pengolahan hasil penelitian menggunakan teknik analisis regresi. Uji signifikansi menggunakan uji-F. Hasil penelitian menunjukkan bahwa: (1) Terdapat kontribusi yang positif dan signifikan dukungan pengembangan karir terhadap kepuasan kerja guru. (2) Terdapat kontribusi yang positif dan signifikan pemberdayaan oleh kepala sekolah terhadap kepuasan kerja. (3) Terdapat kontribusi yang positif dan signifikan dukungan pengembangan karir dan pemberdayaan oleh kepala sekolah secara simultan terhadap kepuasan kerja guru. Mengingat kepuasan kerja sangat penting guna peningkatan motivasi kerja dan produktivitas sekolah, maka guru sebagai anggota terbanyak pada satuan pendidikan hendaknya diberi peluang lebih besar lagi untuk bertumbuh diikuti oleh bantuan pendanaan yang memadai agar karirnya lebih berkembang dengan harapan guru merasa lebih puas dalam bekerja.Kepala sekolah disarankan untuk lebih banyak memberikan tanggung jawab kepada guru sehingga tanpa disadari guru memasuki proses pemberdayaan. Hendaknya, guru secara bergantian ditugaskan mengelola berbagai kegiatan dengan diberikan kewenangan untuk membuat keputusan seizin kepala sekolah. Harapannya guru semakin berkembangan wawasan dan rasa percaya dirinya yang pada gilirannya dapat menambah tingkat kepuasan dalam bekerja.

Kata Kunci: Pengembangan Karir, Pemberdayaan Guru, Kepuasan Kerja

\section{A. Pendahuluan}

Harapan akan Indonesia maju dalam percaturan dunia semakin menguat. Setiap sektor berbenah diri untuk menggapai harapan tersebut. Tidak dipungkiri bahwa sektor pendidikan merupakan sektor yang dominan dapat menjadi sandaran guna tercapainya apa yang dicitacitakan Karena tidak mungkin Indonesia maju dapat terealisasi jika sumber daya manusianya masih jalan di tempat, tidak ada terobosan yang bermakna. Sementara itu salah satu upaya yang dapat dilakukan untuk meningkatkan kompetensi sumber daya manusia Indonesia adalah melalui pendidikan.
Melalui manajemen pendidikan, setiap komponen dalam sistem pendidikan dari mulai pendidik, tenaga kependidikan, peserta didik, kurikulum, dana, sarana dan prasarana ditata dalam rangka menghasilkan output pendidikan sesuai dengan yang dicita-citakan. Penataan unsur-unsur pendidikan itu dilaksanakan dalam kerangka empat kebijakan pokok strategi pendidikan nasional meliputi: (1) pemerataan, (2) peningkatan kualitas, (3) relevansi, (4) efektivitas dan efisiensi pendidikan dengan mengikutsertakan semua pihak yang terkait dengan pendidikan, yaitu pemerintah, keluarga, dan masyarakat. Penataan 
seluruh komponen pendidikan itu diharapkan akan dapat menjamin dihasilkannya lulusan yang bermutu tinggi. Semua itu, dimulai dari proses pembelajaran di kelas, di mana prestasi belajar peserta didik sangat ditentukan oleh kinerja guru di kelas.

Oleh karenanya, dewasa ini semakin kuat tuntutan kepada guru, karena guru merupakan salah satu faktor dominan dalam kegiatan pendidikan. Suatu kegagalan yang terjadi pada sektor pendidikan sering dituduhkan kepada guru. Karena guru dipandang sebagai unsur yang aktif dan lebih menentukan dibandingkan unsur pendidikan lainnya, seperti kurikulum, fasilitas, sarana prasarana serta kebijakan pemerintah. Namun sisi lain, penghargaan dan rasa hormat kepada profesi belum seimbang, sehingga tampak guru terperangkap untuk bekerja keras, tetapi dengan perhatian pada faktor lain yang dapat menunjang guru lebih bersemangat dalam melaksanakan tugasnya masih kurang diperhatikan baik oleh pemerintah maupun unsur lain.

Guru dapat lebih lancar melaksanakan tugasnya manakala semuanya terpenuhi, yaitu kurikulum yang jelas dan visioner, sarana dan prasarana yang memadai sesuai kebutuhan, perlakuan kepegawaian yang wajar. Selain hal tersebut secara psikologis guru juga harus diperhatikan menyangkut kepuasan kerjanya. Seperti yang dikemukakan oleh Ralph, et al. (2001:18) bahwa "sumber daya terpenting dari suatu organisasi adalah pekerjanya". Oleh sebab itu, organisasi menuntut peran aktif dari karyawan untuk dapat memberikan sumbangan berupa hasil kerja yang baik bagi organisasi agar tujuan organisasi tercapai. Karyawan akan dapat memberikan sumbangan berupa hasil kerja yang baik, apabila merasakan pekerjaannya dapat memberikan kepuasan.

Dalam menuju ketercapaian kepuasan kerja guru terdapat beberapa variabel yang mempengaruhi, di antaranya: gaya kepemimpinan, budaya dan iklim sekolah, sarana dan prasarana, peluang karir, pemberdayaan oleh kepala sekolah sebagai pimpinan satuan pendidikan, dan lain sebagainya. Tetapi agar penelitian yang dilaksanakan lebih fokus, maka penulis mencoba mengonsentrasikan variabel pemberdayaan oleh kepala sekolah dan peluang karir guru ke 
depannya dilihat dari faktor yang mendorong lancarnya atau mulusnya karir guru. Pemberdayaan oleh kepala sekolah dianggap menarik untuk dilihat kontribusinya terhadap kepuasan kerja, karena melalui pembinaan oleh kepala sekolah guru merasa terperhatikan, sehingga manakala ada kesalahan dapat segera disadari dan diperbaiki, bertambahnya wawasan dan pengalaman yang dapat mendorong rasa percaya diri guru itu sendiri. Sementara itu, faktor yang mendorong kelancaran peluang berkarir perlu diperhatikan, karena lancar dan terbukanya peluang karir diduga memiliki kontribusi yang signifikan terhadap kepuasan kerja guru.

\section{Kepuasan Kerja Guru}

Kepuasan merupakan suatu pernyataan yang menunjukan respons psikis yang ditampilkan oleh seseorang terhadap suatu fenomena yang dirasakannya. Banyak pengertian yang dimunculkan oleh para ahli mengenai pengertian kepuasan. Kepuasan kerja adalah "sikap seseorang pekerja terhadap pekerjaannya. Kepuasan kerja muncul apabila keuntungan yang dirasakan dari pekerjaannya melampaui batas marjinal yang dikeluarkan dan oleh karyawan dianggap memadai (Gary, 1996:137). Kepuasan kerja itu dihasilkan dari persepsi pegawai terhadap, pekerjaannya, berpangkal dari berbagai aspek kerja seperti upah, kesempatan promosi, penyelia (supervisor) dan rekan sekerja, selain didasarkan kepada faktor lingkungan kerja seperti gaya penyeliaan (supervisi), kebijakan dan prosedur, keanggotaan kelompok kerja, kondisi kerja dan tunjangan Gibson (2004:6768). Kepuasan kerja pada intinya adalah "sebagai selisih dari banyaknya sesuatu yang seharusnya ada dengan banyaknya apa yang ada. Sesuatu yang seharusnya ada didefinisikan sebagai jumlah minimum yang diperlukan untuk memenuhi kebutuhan yang ada yang menekankan terhadap perimbangan-perimbangan yang adil dan kurang adil atas kebutuhankebutuhan. Sehingga seorang pegawai akan terpuaskan jika tidak ada selisih antara kondisi-kondisi yang diinginkan dengan kondisi yang nyata" (Porter, et.al., 1982:130-131).

Banyak teori yang telah dihasilkan para ahli terkait dengan 
kepuasan kerja antara lain: (1) Discrepancy Theory. Teori ini pertama kali dipelopori oleh Lawler dan Porter, (1967:105), yang mengungkapkan bahwa kepuasan kerja seseorang diukur dengan menghitung selisih antara apa yang seharusnya dengan kenyataan yang dirasakan. Kepuasan kerja seseorang tergantung kepada kesenjangan (discrepancy) antara keharusan (expectation needs atau values) dengan apa yang menurut perasaannya atau persepsinya telah diperoleh atau dicapai melalui pekerjaan. Dengan demikian orang akan merasa puas bila tidak ada perbedaan antara yang diinginkan dengan kenyataan, karena batas minimum yang dinginkan, telah terpenuhi. Apabila yang didapat ternyata lebih besar dari pada yang diinginkan maka orang akan menjadi lebih puas, walaupun terdapat kesenjangan tetapi merupakan kesenjangan yang positif. Sebaliknya makin jauh dari keinginan yang dirasakan karena di bawah standar minimum sehingga menimbulkan negative discrepancy, maka makin besar pula ketidak puasan seseorang terhadap pekerjaan. (2) Equity Theory. Teori ini pertama kali dikemukakan oleh Zalesnik yang dikutip oleh Locke. Prinsip dari teori ini mengungkapkan bahwa orang akan merasa puas tergantung apakah ia merasakan adanya keadilan (equity) atau tidak atas suatu situasi. Perasaan equity dan inequity atas situasi diperoleh seseorang dengan cara membandingkan dirinya dengan orang lain yang sekelas, sekantor maupun satu tempat tertentu. Menurut teori ini elemen-elemen dari equity ada tiga yaitu: input-outcome, comparison, dan equity-inequity. Input adalah segala sesuatu yang berharga yang dirasakan karyawan sebagai sumbangan terhadap pekerjaan. Contoh: Pendidikan, pengalaman, keterampilan, jumlah upah, jumlah jam kerja dan sebagainya. Adapun yang dimaksud dengan outcome adalah segala sesuatu yang berharga, yang dirasakan karyawan sebagai hasil dari pekerjaannya, seperti: fringe benefit status symbols, recognition, opportunity for achievement of self-expression.

Menurut Gibson dkk. bahwa dimensi kepuasan kerja adalah (1) upah: jumlah uang yang diterima dan dianggap upah yang wajar; 
pekerjaan: sampai sejauh mana tugas kerja dianggap menarik dan memberikan kesempatan untuk belajar dan menerima tanggung jawab; (3) kesempatan promosi: adanya kesempatan untuk maju; (4) penyelia: kemampuan untuk memperlihatkan ketertarikan dan perhatian kepada pegawai; (5) rekan sekerja: sampai sejauh mana rekan sekerja bersahabat dan mendukung.

Kepuasan kerja adalah cara seorang pekerja merasakan pekerjaannya serta generalisasi sikap-sikap terhadap pekerjaanya yang didasarkan atas aspek-aspek pekerjaanya yang bermacam-macam Wexley dan Yulk (1999:129). Kepuasan kerja yang dialami seseorang lebih banyak ditentukan oleh bentuk pekerjaan, lingkungan pekerjaan, keadaan pekerjaan, pemenuhan kebutuhan pekerja, semua ini menjadi dasar munculnya rasa puas seorang pekerja dalam bekerja (Durbin, 2000:293). Maslow seperti yang dikutip oleh Goble (2001:72) menyatakan bahwa selama hidup praktis manusia selalu mendambakan sesuatu. Manusia adalah binatang yang berhasrat dan jarang mencapai taraf kepuasan yang sempurna, kecuali untuk suatu saat yang terbatas. Begitu suatu hasrat berhasil dipuaskan segera muncul hasrat lain sebagai gantinya (Maslow dalam Goble, 2001:72).

Kepuasan kerja dapat dinikmati dalam pekerjaan ataupun di luar pekerjaan dan dapat terjadi kombinasi dalam dan luar pekerjaan. Kepuasan kerja dalam pekerjaan adalah kepuasan kerja yang dinikmati dalam pekerjaan dengan memperoleh pujian hasil kerja yang baik. Guru yang lebih suka menikmati kepuasan kerja dalam pekerjaannya melaksanakan proses kegiatan belajar mengajar disekolah dengan motivasi tinggi dan semangat yang tinggi. Berdasarkan hasil kajian teoritis tentang kepuasan kerja guru, maka dapat dikatakan bahwa: (1) Tingkat kepuasan masing-masing guru berbeda karena sifat pribadi orang tidak sama. (2) Tidak ada discrepancy yakni selisih yang diterima guru dari hasil kerja nyata dengan yang seharusnya diterima sebagai balas jasanya. (3) Faktor yang dekat dengan masalah discrepancy adalah equity yakni perasaan adil. Bila seorang guru diperlakukan tidak adil oleh kepala sekolah dibandingkan dengan guru lainnya sedangkan tanggung 
Didaktik : Jurnal IImiah PGSD STKIP Subang, ISSN Cetak : 2477-5673 ISSN Online : 2614-722X Volume VI Nomor 01, Juni 2020

jawabnya sama atau bahkan lebih besar tanggung jawabnya daripada guru yang lainnya, maka timbul faktor ketidakpuasan kerja yang akan mempengaruhi tingkah lakunya. (4) Kepuasan kerja guru timbul oleh beberapa faktor lain seperti pengharapan atas prestasi kerjanya (reward), hubungan antar individu (guru, kepala sekolah dan staf tata usaha) di sekolah (human relation), lingkungan kesejahteraan karyawan sekolah, peluang untuk karir dan status sosial.

Berbicara tentang perasaan sangat pribadi dan sangat tergantung pada kondisi orang yang bersangkutan, yakni suasana hati, perasaan dalam arti sempit, dan emosi orang yang bersangkutan. Oleh karena itu, dalam penelitian ini yang dimaksud dengan kepuasan kerja guru adalah perasaan atau tanggapan guru terhadap bentuk, lingkungan, keadaan pekerjaan serta pemenuhan kebutuhan dalam pekerjaannya yang secara emosional terungkap melalui pengalamannya, dengan dimensi: (1) Bentuk pekerjaan; (2) Lingkungan pekerjaan; (3) Keadaan pekerjaan;

Pemenuhan kebutuhan (Durbin, 2000:293).

\section{Pengembangan Karier}

Organisasi dalam perkembangannya selalu menginginkan kemajuan dalam berbagai hal terutama tumbuhnya organisasi melalui produktifitas kerja pegawainya. "Ketidak puasan yang disebabkan prospek karier menjadi masalah utama terjadinya turnover pada organisasi perusahaan" (Armstrong, 2002:210). Dalam Snell (2002:324), dan Castetter (2002:244) dijelaskan pentingnya hubungan pengembangan staf dengan jenjang karier, dimana proses pengembangan karier merupakan bagian dari program pengembangan pegawai. Dalam hal ini organisasi tidak bisa melepaskan diri dari harapan-harapan pegawai untuk mengembangkan karier, karena pengembangan karier itu merupakan bagian dari pertumbuhan organisasi dan hak pegawai untuk mendapatkannya. Sumber Daya Manusia (SDM) yang baik "ditujukan kepada peningkatan kontribusi yang dapat ditentukan oleh para pekerja dalam organisasi kearah terciptanya tujuan organisasi" (Siagian, 2005:27). Pengembangan karier sebagai suatu proses SDM yang penting dan 
strategis bagi peningkatan kinerja pegawai dan organisasi. Mody dan Noe (2006:336) mengartikan pengembangan karier sebagai "suatu pendekatan formal yang digunakan oleh organisasi untuk menjamin tersedianya pegawai yang sesuai dengan kwalitas, yang berpengalaman ketika dibutuhkan" Hall DT dalam Robbins (2008:215) menjelaskan: "Hakikat dari suatu program pengembangan karier progresif dibangun di atas pemberian dukungan atas karyawan untuk secara terus menerus meningkatkan keterampilan, kemampuan dan pengetahuan mereka". Dukungan ini mencakup: (1) Mengkomunikasikan secara jelas tujuan dan strategi masa depan organisasi. Bila orang tahu di mana organisasi berpusat, mereka lebih mampu mengembangkan rencana pribadi mereka untuk berbagi masa depan tersebut. (2) Menciptakan peluang pertumbuhan. Karyawan hendaknya memiliki peluang untuk mendapatkan pengalaman kerja yang baru, menarik dan secara professional menantang. (3) Menawarkan bantuan keuangan. Perusahaan hendaknya menawarkan penggantian uang kuliah untuk membantu karyawan tetap mengikuti perkembangan terbaru.

Menyediakan waktu bagi karyawan untuk belajar. Organisasi hendaknya bermurah hati dalam membayar waktu cuti dari kerja untuk keperluan palatihan di luar waktu kerja. Selain itu, muatan kerja seharusnya tidak begitu menuntut sehingga tidak menghalangi karyawan untuk memperoleh waktu dalam mengembangkan ketrampilan, kemampuan dan pengetahuan baru.

Pengembangan karier lebih diarahkan pada kebutuhan akan pegawai yang sesuai dengan karakteristik pekerjaan. Tiga yang tidak dapat dipisahkan dalam pengertian tersebut adalah: pengembangan karier, kebutuhan individual dan kebutuhan organisasional. Hal ini didukung Bernardin and Russel (1993:340) sebagai berikut: "A career development system is a formal organized, planned effort to achieve a balance between individual career needs and organizational work force requirement. It is mechanism for meeting he present and future human resources nedds of an organization". Pengertian tersebut menjelaskan bahwa program pengembangan karier bertujuan mengembangkan 
Didaktik : Jurnal IImiah PGSD STKIP Subang, ISSN Cetak : 2477-5673 ISSN Online : 2614-722X Volume VI Nomor 01, Juni 2020

keseimbangan

antara

pengembangan potensi pegawai dengan kebutuhan perusahaan atau dengan kata lain kebutuhan dan keinginan pegawai dipertemukan dengan kebutuhan organisasi. Flippo (2001:278) mengemukakan bahwa suatu program pengembangan karier yang dirancang dengan tepat menyangkut tiga unsur utama, yaitu: (1) membantu pegawai dalam menilai kebutuhan karier internalnya, (2) mengembangkan, membuka dan menyiarkan kesempatan karier dalam oraganisasi, (3) menghubungkan antara kebutuhan kesempatan akan karier dan kemampuan yang dimiliki karyawan.

\section{Dalam suatu pengembangan} karier akan terkandung kegiatankegiatan seperti training, promosi, development dan sebagaimanya. Casio (2002:364-366) menyampaikan bahwa "aktivitas-aktivitas manajemen karier untuk pengembangannya dapat dilaksanakan dalam bentuk internal staffing yang termasuk di dalamnya adalah promotion and lateral transfers". Sedangkan Flippo (2001:291) program pengembangan karier yang efektif adalah yang berhubungan dengan penyesuaian karier yang diberikan sesuai dengan

kebutuhan organisasi melalui program pendidikan, pelatihan, pemindahan dan promosi yang berkesinambungan. Menurut Fieldman and Arnold (1993:95), kunci pengembangan karier yang sukses adalah: (1). Organisasi harus menilai para pegawai secara berkala sepanjang karier mereka untuk mengetahui kekuatan individu yang dapat dipergunakan dalam pekerjaan lain dalam organisasi dan untuk memperbaiki kelemahan yang merintangi jalannya karier, (2). Organisasi harus memberi informasi yang lebih jelas realistis kepada para pegawai tidak hanya apabila organisasi itu mengambil keputusankeputusan mengenai pegawai, tetapi juga apabila mengambil keputusankeputusan mengenai promosi; kegiatan-kegiatan perencanaan karier menjadi sukses apabila kegiatankegiatan itu dikoordinasikan dengan kegiatan-kegiatan lain dalam manajemen sumber daya manusia seperti seleksi, latihan, perencanaan SDM, dan penilaian kinerja.

Kebijakan pengembangan
karier harus diarahkan bagi
pertumbuhan pribadi, perkembangan
profesional, perbaikan lembaga,
mobilitas ke atas, dan efektifitas


Didaktik : Jurnal IImiah PGSD STKIP Subang, ISSN Cetak : 2477-5673 ISSN Online : 2614-722X Volume VI Nomor 01, Juni 2020

jabatan dengan memperhatikan jenis dan jenjang pendidikan, usia dan jenis kelamin, pengalaman kerja, pengalaman organisasi, pengalaman luar negeri, kinerja, serta loyalitas dan dedikasi (Sutisna, 2002:23). Syarat-syarat tersebut menjadi kriteria bagi pemilihan orang yang tepat bagi jabatan yang tepat pula.

"Pengembangan karier adalah upaya pribadi seseorang pegawai untuk mencapai rencana karier" (Handoko, 2014:131).

Pengembangan karier berpusat sekitar kebutuhan yang dihubungkan dengan kegiatan dan minat pegawai. Pengembangan karier menunjukkan adanya peningkatan-peningkatan status seseorang dalam jalur karier yang telah ditetapkan. Sehingga dengan adanya pengembangan karier ini dapat memberikan motivasi kepada pegawai dalam mengembangkan karier dalam pekerjaannya dengan cara meningkatkan pengetahuan, sikap dan ketrampilan.

Dalam konteks individu pengembangan karier dengan maksud meningkatkan status dan gaji, memastikan keselamatan pekerjaan dan mempertahankan kemampuan dalam pasar tenaga kerja yang berubah. Pengembangan karier merupakan suatu proses yang berkelanjutan memberikan kesempatan kepada pegawai untuk mengembangkan minat, kebutuhan dan pilihan karier dalam organisasi. Melalui pengembangan karier pegawai dibantu untuk menentukan tujuan realistis dan kemampuankemampuan yang diperlukan untuk jabatan yang disandangnya. Pengembangan karier adalah upaya pribadi seseorang pegawai untuk mencapai rencana karier. Pengembangan karier berpusat sekitar kebutuhan yang dihubungkan dengan kegiatan dan minat pegawai. Pengembangan karier menunjukkan adanya peningkatan-peningkatan status seseorang dalam jalur karier yang telah ditetapkan. Adapun yang dimaksud dukungan pengembangan karir adalah upaya yang dilakukan oleh kepala sekolah atau pimpinan institusi pendidikan terhadap guru melalui komunikasi yang transparan, pemberian peluang untuk berkembang, bantuan keuangan dan kesempatan bagi guru untuk belajar., dengan dimensi: (1) Komunikasi; (2) Peluang pertumbuhan; (3) Bantuan 
keuangan; (4) Waktu untuk belajar (Robbins, 2002:215).

\section{Pemberdayaan oleh Kepala}

\section{Sekolah}

Terdapat perbedaan definisi pemberdayaan (empowerment) yang dikemukakan oleh para ahli. Wakhibur Rokhman (Usmara, 2003:121) mengatakan bahwa pemberdayaan adalah salah satu strategi untuk memperbaiki sumber daya manusia dengan pemberian tanggung jawab dan kewenangan terhadap mereka yang nantinya diharapkan dapat memungkinkan mereka mencapai kinerja yang lebih tinggi di era yang selalu berubah. Menurut Payne (Adi, 2003:162), pemberdayaan pada intinya ditujukan guna membantu klien memperoleh daya untuk mengambil keputusan dan menentukan tindakan yang akan ia lakukan yang terkait dengan diri mereka, termasuk mengurangi efek hambatan pribadi dan sosial dalam melakukan tindakan. Hal ini dilakukan melalui peningkatan kemampuan dan rasa percaya diri untuk menggunakan daya yang ia miliki, antara lain melalui transfer daya dari lingkungan. Sementara Shardlow (Adi, 2003:162) mengatakan bahwa pada intinya pemberdayaan

membahas

bagaimana individu, kelompok maupun komunitas berusaha mengontrol kehidupan mereka sendiri dan mengusahakan untuk membentuk masa depan sesuai dengna keinginan mereka.

Menurut Noe et, al (Usmara, 2003:123) bahwa pemberdayaan adalah merupakan pemberian tangung jawab dan wewenang terhadap pekerja untuk mengambil keputusan menyangkut semua pengembangan produk dan pengambilan keputusan. Sedangkan Byars dan Rue (Usmara, 2003:123) memberi pengertian bahwa empowerment merupakan bentuk desentralisasi yang melibatkan pada bawahan dalam membuat keputusan. Selanjutnya Khan (Usmara, 2003:123) menyatakan bahwa pemberdayaan merupakan hubungan antar personal yang berkelanjutan untuk membangun kepercayaan antara karyawan dan manajemen.

Andi Kirana (Sholeh, 2008) mengatakan bahwa kepemimpinan yang memberdayakan, mengimplikasikan suatu keinginan untuk melimpahkan tanggung jawab dan berusaha membantu dalam menentukan kondisi dimana orang 
lain dapat berhasil. Oleh karena itu, seorang pemimpin harus menjelaskan apa yang dharapkannya, harus menghargai kontribusi setiap orang, harus membawa lebih banyak orang keluar "kotak organisasi" dan harus mendorong setiap orang untuk berani mengemukakan pendapat. Sesuai dengan pendapat Mc Kenna \& Beech (2000:18) bahwa pemberdayaan bersifat mendukung budaya dan tidak menyalahkan karena kesalahan dianggap kesempatan untuk belajar.

Sejalan dengan pendapat tersebut, Luthan mengatakan bahwa pemberdayaan merupakan pelibatan guru yang benar-benar berarti. Pemberdayaan (empowerment) adalah wewenang untuk membuat keputusan dalam satu area kegiatan operasi tertentu tanpa harus memperoleh pengesahan orang lain (Eka, 2007). Sementara Ford mengatakan bahwa pemberdayaan juga berarti saling berbagi informasi dan pengetahuan diantara guru yang digunakan untuk memahami dan mendukung kinerja organisasi, pemberian penghargaan atas kinerja organisasi dan pemberian otonomi dalam pengambilan keputusan yang berpengaruh pada organisasi (Eka, 2007).

Pada dasarnya pemberdayaan merupakan pelepasan atau pembebasan, bukan pengendalian energi manusia yang dilakukan dengan meniadakan segala peraturan, prosedur, perintah dan lain-lain yang tidak perlu, yang merintangi organisasi untuk mencapai tujuannya. Menurut Stewart IM (Sholeh, 2008), pemberdayaan bertujuan menghapuskan hambatan-hambatan sebanyak mungkin guna membebaskan organisasi dan orangorang yang bekerja di dalamnya, melepaskan mereka dari halanganhalangan yang hanya memperlambat reaksi dan merintangi aksi mereka.

Menurut Mulyadi dan Setiyawan (Sholeh, 2008), untuk mewujudkan suatu pemberdayaan dalam organisasi, seorang pemimpin harus memahami tiga keyakinan dasar berikut ini: (1) Subsidiarity. Prinsip ini mengajarkan bahwa badan yang lebih tinggi kedudukannya tidak boleh mengambil tanggung jawab yang dapat dan harus dilaksanakan oleh badan yang berkedudukan lebih rendah. Dengan kata lain, mencuri tanggung jawab orang merupakan 
suatu kesalahan, karena keadaan ini akhirnya menjadikan orang tersebut tidak terampil. Kenyataannya, di masa lalu organisasi lebih banyak dirancang untuk memastikan bahwa kesalahan tidak pernah terjadi. Dalam jargon lama, pengambilalihan tanggung jawab bawahan oleh atasan merupakan hal yang normal terjadi, dan dibenarkan dengan suatu alasan bahwa suatu organisasi dibentuk untuk menghindari kesalahan. (2) Staf pada dasarnya baik. Inti pemberdayaan staf adalah keyakinan bahwa orang pada dasarnya baik. Meskipun kadangkadang orang gagal, dan kadangkadang orang melakukan kesalahan, namun tujuan orang adalah menuju kebaikan. Sebagai manusia yang berakal sehat dan makhluk yang berfikir, orang memiliki kecenderungan alami untuk berhasil dalam pekerjaannya. Untuk dapat memberdayakan guru, kepala sekolah harus secara sederhana yakin bahwa "sepanjang masa, hampir setiap guru, hampir selalu, akan menggunakan kekuatannya dalam mewujudkan visinya dan dipandu oleh nilai-nilai kebaikan." Pemberdayaan guru dapat dipandang sebagai pemerdekaan, karena dengan pemberdayaan, kepala sekolah tidak lagi menggunakan pengawasan, dan mengatur aktivitas guru yang bekerja. Kepala sekolah melakukan pemberdayaan dengan memberikan pelatihan dan teknologi yang memadai kepada guru, memberikan arah yang benar, dan membiarkan guru untuk mengerjakan semua yang dapat dikerjakan oleh mereka. (3) Trust-based relationship. Pemberdayaan staf menekankan aspek kepercayaan yang diletakkan oleh manajemen kepada staf. Dari pemberdayaan guru, hubungan yang tercipta antara kepala sekolah dengan guru adalah hubungan berbasis kepercayaan (trust-based relationship) yang diberikan oleh kepala sekolah kepada guru, atau sebaliknya kepercayaan yang dibangun oleh guru melalui kinerjanya.

Lebih lanjut Stewart (Sholeh, 2008) mengatakan ada enam cara yang dapat digunakan pemimpin dalam mengembangkan pemberdayaan staf/bawahan, yakni: meningkatkan kemampuan staf/bawahan (enabling), memperlancar (facilitating) tugastugas mereka, konsultasi (consulting), bekerjasama (collaborating), 
membimbing (mentoring) bawahan, dan mendukung (supporting). Namun apapun cara yang ditempuh oleh pemimpin dalam memberdayakan staf/bawahan, menurut Sarah Cook dan Steve Macaulay (Sholeh, 2008), kepemimpinan yang memberdayakan perlu mengacu pada empat dimensi, yaitu visi, realita, orang (manusia), dan keberanian.

Dari beberapa definisi tersebut di atas, dapat diambil beberapa hal penting dalam pemberdayaan, yaitu adanya pemberian tanggung jawab dan wewenang kepada guru dalam pembuatan keputusan, adanya kondisi saling percaya antara guru dan manajemen (kepala sekolah), dan adanya pelibatan guru (employee involment) dalam pengambilan keputusan. Pemberdayaan ditujukan untuk memperoleh manfaat dari kreatifitas guru dan mendorong pemikiran dan inisiatif yang independen.

Pemikiran dan inisiatif kreatif sebanyak mungkin oleh guru akan memungkinkan adanya ide dan keputusan yang lebih baik, kualitas yang lebih baik, produktivitas yang lebih tinggi dan sebagai hasilnya daya saing yang makin meningkat. Hakekat dari pemberdayaan adalah bahwa pemberdayaan merupakan cara terbaik untuk mengarahkan kreativitas dan inisiatif dari para guru/individu ke arah peningkatan daya saing organisasi (sekolah). Pemberdayaan merupakan kunci utama dalam motivasi kinerja. Seorang guru yang merasa dirinya dihargai memliki kontribusi, akan berkembang secara pribadi sehingga kontribusinya bagi sekolah dapat dioptimalkan. Dengan kata lain pemberdayaan guru adalah upaya kepala sekolah dalam mengoptimalkan kinerja guru melalui pemberian tanggung jawab dan kewenangan yang lebih besar serta dilibatkan dalam pengembangan produk dan pembuatan keputusan. Adapun dimensi untuk mengukur pemberdayaan oleh kepala sekolah, meliputi:

(1) Pemberian tanggungjawab; (2) Pemberian wewenang; (3) Keputusan pengembangan produk; Pengambilan keputusan (Noe, et.al. dalam Usmara, 2003:123)

\section{B. Metode Penelitian}

Metode yang digunakan adalah metode survey, yaitu pengumpulan data menggunakan 
instrumen penelitian untuk meminta jawaban dari responden. Lebih jauh, metode penelitian yang digunakan adalah metode deskriptif analisis, dengan menggunakan teknik survey kuesioner. Dengan metode survey ini dapat dikemukakan ada tidaknya pengaruh antar variabel bebas/prediktor, yaitu pengembangan karir dan pemberdayaan oleh kepala sekolah terhadap variabel terikat/respons, yaitu kepuasan kerja guru. Analisis yang digunakan adalah analisis regresi parsial dan regresi ganda.

Adapun yang menjadi populasi dalam penelitian ini adalah seluruh guru sekolah dasar (SD) Negeri pada Gugus Kartini di Kecamatan Patrol Kabupaten Indramayu yang berjumlah 56 orang. Oleh karena jumlah respondennya kurang dari 100 orang, maka dalam penelitian ini seluruh populasi menjadi responden atau sampel jenuh.

Teknik pengumpulan data dengan cara memberi seperangkat pertanyaan atau pernyataan tertulis kepada responden untuk dijawabnya". Angket yang digunakan dalam penelitian ini adalah angket tertutup (angket berstruktur) artinya angket yang disajikan dalam bentuk sedemikian rupa sehingga responden diminta untuk memilih satu jawaban yang sesuai dengan karakteristik dirinya dengan cara memberikan tanda checklist $(\sqrt{ })$. Angket yang digunakan dalam penelitian ini adalah dalam bentuk forced choice.

\section{Hasil Penelitian dan}

\section{Pembahasan}

Untuk mengetahui besaran kontribusi dukungan pengembangan karir secara individual (parsial) terhadap kepuasan kerja guru dapat dilihat dari nilai $t$ pada tabel Coefficients dibawah ini.

Tabel 1: Persamaan Regresi Kontribusi Dukungan Pengembangan Karir terhadap Kepuasan kerja Guru

Coefficientsa

\begin{tabular}{|c|c|c|c|c|c|}
\hline & \multicolumn{2}{|c|}{$\begin{array}{l}\text { Unsta } \\
\text { ndardi } \\
\text { zed } \\
\text { Coeffi } \\
\text { cients }\end{array}$} & $\begin{array}{l}\text { Stand } \\
\text { ardize } \\
\text { d } \\
\text { Coeffi } \\
\text { cients }\end{array}$ & $\mathrm{t}$ & $\mathrm{Si}$ \\
\hline & & $\begin{array}{l}\text { St } \\
\text { d. } \\
\text { Er } \\
\text { ro }\end{array}$ & Beta & & \\
\hline
\end{tabular}




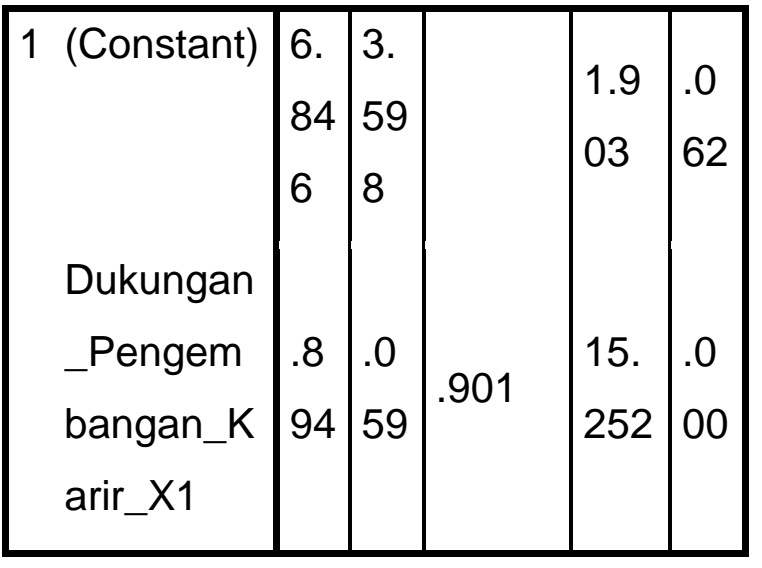

Berdasarkan tabel hasil uji $\mathrm{t}$

diperoleh bahwa nilai thitung variabel dukungan pengembangan karir memiliki nilai sebesar $p$-value $0,000<$ 0,05 artinya berdistribusi signifikan. Hal tersebut berarti dukungan pengembangan karir secara parsial berkontribusi terhadap kepuasan kerja guru. Persamaan regresi $y=a$ $\mathrm{bx} 1$ dari hasil perhitungan diperoleh $\mathrm{y}$ $=6,846+0,894 \mathrm{X}_{1}$. Konstanta sebesar 6,846 menyatakan bahwa jika ada kenaikan nilai dari variabel dukungan pengembangan karir, maka kepuasan kerja guru adalah 6,846. Koefesien regresi sebesar 0,894 menyatakan bahwa setiap perubahan satu skor atau nilai dukungan pengembangan karir akan memberikan skor 0,894.

Uji F untuk menguji signifikansi konstanta dan variabel dependen (kepuasan kerja guru). Dasar pengambilan keputusan yaitu dengan membandingkan $F$ hitung dengan nilai $F$ tabel sebagai berikut: jika nilai signifikansi $<0,05$, maka Ho ditolak artinya koefesien regresi signifikan, dan sebaliknya.

Tabel 2: Signifikansi Kontribusi Variabel Dukungan Pengembangan Karir terhadap Kepuasan Kerja Guru

\section{ANOVA}

\begin{tabular}{|c|c|c|c|c|c|}
\hline Model & $\begin{array}{l}\text { Sum } \\
\text { of } \\
\text { Squ } \\
\text { ares }\end{array}$ & $\begin{array}{l}d \\
f\end{array}$ & $\begin{array}{l}\text { Mea } \\
n \\
\text { Squa } \\
\text { re }\end{array}$ & $\mathrm{F}$ & $\mathrm{Si}$ \\
\hline $\begin{array}{l}1 \text { Regr } \\
\text { essio } \\
\mathrm{n} \\
\text { Resi } \\
\text { dual } \\
\text { Total }\end{array}$ & $\begin{array}{l}1949 \\
.114 \\
452 . \\
440 \\
\\
2401 \\
.554\end{array}$ & 1 & $\begin{array}{l}1949 \\
.114 \\
8.37 \\
9\end{array}$ & \begin{tabular}{|l}
232 \\
.63 \\
2
\end{tabular} & \begin{tabular}{|l}
.0 \\
00 \\
$b$
\end{tabular} \\
\hline
\end{tabular}

a. Dependent Variable: Kepuasan_Kerja_Guru_Y

b. Predictors: (Constant), Dukungan_Pengembangan_Karir X1

Berdasarkan tabel hasil uji anova atau $F$ test didapat $F$ hitung sebesar 232,632 dan nilai signifikansi $0,000<0,05$. Dengan 
Didaktik : Jurnal IImiah PGSD STKIP Subang, ISSN Cetak : 2477-5673 ISSN Online : 2614-722X Volume VI Nomor 01, Juni 2020

demikian $\mathrm{H}_{0}$ ditolak artinya kontribusi dukungan pengembangan karir terhadap kepuasan kerja guru adalah signifikan.

Selanjutnya untuk mengetahui besaran kontribusi dukungan pengembangan karir terhadap kepuasan kerja guru dapat dilihat dari hasil perhitungan koefesien determinasi pada tabel dibawah ini:

Tabel 3: Besaran Kontribusi Variabel Dukungan Pengembangan Karir terhadap Kepuasan Kerja Guru

\section{Model Summary}

\begin{tabular}{|c|c|c|c|c|}
\hline $\mathrm{M}$ & $\mathrm{R}$ & \begin{tabular}{l|} 
R \\
Squa \\
re
\end{tabular} & 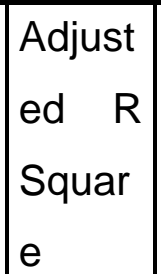 & $\begin{array}{l}\text { Std. } \\
\text { Error of } \\
\text { the } \\
\text { Estimate }\end{array}$ \\
\hline 1 & $\begin{array}{l}.90 \\
1^{\mathrm{a}}\end{array}$ & 812 & .808 & 2.895 \\
\hline
\end{tabular}

a. Predictors: (Constant), Dukungan_Pengembangan_Karir X1

Dari tabel di atas terlihat bahwa $R$ Square sebesar 0,812 , hal ini berarti bahwa $0,812 \times 100 \%=$ $81,2 \%$ kepuasan kerja guru mendapat kontribusi dari variabel dukungan pengembangan karir, sedangkan sisanya $18,8 \%$ mendapat kontribusi dari faktor lain yang tidak diteliti.

Untuk mengetahui besaran kontribusi pemberdayaan oleh kepala sekolah secara individual (parsial) terhadap kepuasan kerja guru dapat dilihat dari nilai $t$ pada tabel Coefficients dibawah ini.

Tabel 4: Persamaan Regresi

Kontribusi Pemberdayaan oleh Kepala Sekolah terhadap Kepuasan kerja Guru

\section{Coefficients $^{\mathrm{a}}$}

\begin{tabular}{|c|c|c|c|c|c|}
\hline & $\begin{array}{l}\text { Unst } \\
\text { dard } \\
\text { d } \\
\text { Coef } \\
\text { ents }\end{array}$ & $\begin{array}{l}\tan \\
\text { lize } \\
\text { ffici }\end{array}$ & $\begin{array}{l}\text { Stand } \\
\text { ardize } \\
\text { d } \\
\text { Coeffi } \\
\text { cients }\end{array}$ & 列 & $\begin{array}{l}\mathrm{Si} \\
\text { g. }\end{array}$ \\
\hline Model & B & $\begin{array}{l}\text { St } \\
\text { d. } \\
\text { Er } \\
\text { ro } \\
\text { r }\end{array}$ & Beta & & \\
\hline $\begin{array}{l}1 \text { (Constan } \\
\text { t) }\end{array}$ & $\begin{array}{l}14 . \\
297\end{array}$ & $\begin{array}{l}7 . \\
31 \\
9\end{array}$ & & $\begin{array}{l}1 . \\
95 \\
3\end{array}$ & $\begin{array}{l}.0 \\
56\end{array}$ \\
\hline $\begin{array}{l}\text { Pemberd } \\
\text { ayaan_ol } \\
\text { eh_Kase } \\
\text { k_X2 }\end{array}$ & $\begin{array}{l}.75 \\
2\end{array}$ & $\begin{array}{l}.1 \\
16\end{array}$ & .660 & $\begin{array}{l}6 . \\
46 \\
4\end{array}$ & $\begin{array}{l}.0 \\
00\end{array}$ \\
\hline
\end{tabular}


Didaktik : Jurnal IImiah PGSD STKIP Subang, ISSN Cetak : 2477-5673 ISSN Online : 2614-722X Volume VI Nomor 01, Juni 2020

Berdasarkan tabel hasil uji $\mathrm{t}$ diperoleh bahwa nilai thitung variabel pemberdayaan oleh kepala sekolah memiliki nilai sebesar $p$-value $0,000<$ 0,05 artinya signifikan. Dengan demikian pemberdayaan oleh kepala sekolah secara parsial berkontribusi terhadap kepuasan kerja guru. Persamaan regresi $y=a b x_{2}$ dari hasil perhitungan diperoleh $\mathrm{y}=$ $14,297+0,752 X_{2}$. Konstanta sebesar 14,297 menyatakan bahwa jika ada kenaikan nilai dari variabel pemberdayaan oleh kepala sekolah, maka kepuasan kerja guru adalah 14,297. Koefesien regresi sebesar 0,752 menyatakan bahwa setiap perubahan satu skor atau nilai pemberdayaan oleh kepala sekolah akan memberikan skor 0,752.

Uji $F$ untuk menguji signifikan konstanta dan variabel dependen (kepuasan kerja guru). Dasar pengambilan keputusan, yaitu dengan membandingkan nilai hitung $F$ dengan nilai tabel $F$ sebagai berikut: Jika nilai hitung $F$ lebih besar dari nilai tabel $\mathrm{F}$, maka $\mathrm{H}_{0}$ ditolak artinya koefisien regresi signifikan, dan sebaliknya.

Tabel 5: Signifikansi Kontribusi Variabel Pemberdayaan oleh Kepala
Sekolah terhadap Kepuasan Kerja

Guru

ANOVA ${ }^{a}$

\begin{tabular}{|c|c|c|c|c|c|}
\hline Model & $\begin{array}{l}\text { Sum } \\
\text { of } \\
\text { Squ } \\
\text { ares }\end{array}$ & df & $\begin{array}{l}\text { Mea } \\
n \\
\text { Squa } \\
\text { re }\end{array}$ & $F$ & $\begin{array}{l}\text { Si } \\
\text { g. }\end{array}$ \\
\hline $\begin{array}{l}1 \text { Regr } \\
\text { essio } \\
\mathrm{n} \\
\text { Resi } \\
\text { dual } \\
\text { Total }\end{array}$ & $\begin{array}{l}1047 \\
.690 \\
1353 \\
.864 \\
\\
2401 \\
.554\end{array}$ & 54 & $\begin{array}{l}1047 \\
.690 \\
25.0 \\
72\end{array}$ & $\begin{array}{l}41 . \\
788\end{array}$ & $\begin{array}{l}.0 \\
00 \\
b\end{array}$ \\
\hline
\end{tabular}

a. Dependent Variable:

Kepuasan_Kerja_Guru_Y

b. Predictors: (Constant),

Pemberdayaan_oleh_Kasek_X2

Berdasarkan table diatas hasil uji anova atau $F$ test didapat $F_{\text {hitung }}$ sebesar 41,788 dan signifikansi $0,000<0,05$ sehingga $H_{\circ}$ ditolak artinya kontribusi pemberdayaan oleh kepala sekolah terhadap kepuasan kerja guru adalah signifikan.

Selanjutnya untuk mengetahui besaran kontribusi pemberdayaan oleh kepala sekolah terhadap kepuasan kerja guru dapat dilihat 
Didaktik : Jurnal IImiah PGSD STKIP Subang, ISSN Cetak : 2477-5673 ISSN Online : 2614-722X Volume VI Nomor 01, Juni 2020

dari hasil perhitungan koefesien determinasi pada tabel dibawah ini:

Tabel 6: Besaran Kontribusi Variabel Pemberdayaan oleh Kepala Sekolah terhadap Kepuasan Kerja Guru

\section{Model Summary}

\begin{tabular}{|c|c|c|c|c|}
\hline $\begin{array}{l}\text { Mo } \\
\text { del }\end{array}$ & $\mathrm{R}$ & \begin{tabular}{l|} 
R \\
Squa \\
re
\end{tabular} & $\begin{array}{ll}\text { Adjust } \\
\text { ed } R \\
\text { Squar } \\
\text { e }\end{array}$ & $\begin{array}{l}\text { Std. } \\
\text { Error } \\
\text { of the } \\
\text { Estim } \\
\text { ate }\end{array}$ \\
\hline 1 & $\begin{array}{l}.6 \\
60 \\
a\end{array}$ & .436 & .426 & 5.007 \\
\hline $\begin{array}{l}\text { a. } \\
\text { Peml }\end{array}$ & & dictors & (Co & $\begin{array}{l}\text { nstant), } \\
\text { (asek_ }\end{array}$ \\
\hline
\end{tabular}

Dari tabel di atas terlihat bahwa $R$ Square sebesar 0,436 , hal ini berarti bahwa $0,436 \times 100 \%=$ $43,6 \%$ kepuasan kerja guru mendapat kontribusi dari variabel pemberdayaan oleh kepala sekolah, sedangkan sisanya $56,4 \%$ mendapat kontribusi dari faktor lain yang tidak diteliti.
Untuk mengetahui besaran kontribusi dukungan pengembangan karir dan pemberdayaan oleh kepala sekolah secara bersama-sama (simultan) terhadap kepuasan kerja guru dapat dilihat dari nilai t pada tabel Coefficients dibawah ini.

Tabel 7: Persamaan Regresi Kontribusi Dukungan Pengembangan Karir dan Pemberdayaan oleh Kepala Sekolah Secara Simultan terhadap Kepuasan Kerja Guru

\section{Coefficients $^{\mathrm{a}}$}

\begin{tabular}{|c|c|c|c|c|c|}
\hline & $\begin{array}{l}\text { Uns } \\
\text { nda } \\
\text { zed } \\
\text { Coe } \\
\text { cier }\end{array}$ & $\begin{array}{l}\text { sta } \\
\text { ardi } \\
\text { effi } \\
\text { nts }\end{array}$ & $\begin{array}{l}\text { Stand } \\
\text { ardize } \\
\text { d } \\
\text { Coeffi } \\
\text { cients }\end{array}$ & $\mathrm{t}$ & $\begin{array}{l}\mathrm{Si} \\
\text { g. }\end{array}$ \\
\hline Model & B & $\begin{array}{l}\text { St } \\
\text { d. } \\
\text { Er } \\
\text { ro } \\
\text { r }\end{array}$ & Beta & & \\
\hline 1 (Constant) & $\begin{array}{l}5 . \\
54 \\
3\end{array}$ & $\begin{array}{l}4 . \\
34 \\
2\end{array}$ & & $\begin{array}{l}1.2 \\
76\end{array}$ & $\begin{array}{l}.2 \\
07\end{array}$ \\
\hline $\begin{array}{l}\text { Dukungan_ } \\
\text { Pengemba } \\
\text { ngan_Karir } \\
\text { X1 }\end{array}$ & $\begin{array}{l}.8 \\
62\end{array}$ & $\begin{array}{l}.0 \\
84\end{array}$ & .868 & $\begin{array}{l}10 . \\
319\end{array}$ & $\begin{array}{l}.0 \\
00\end{array}$ \\
\hline
\end{tabular}




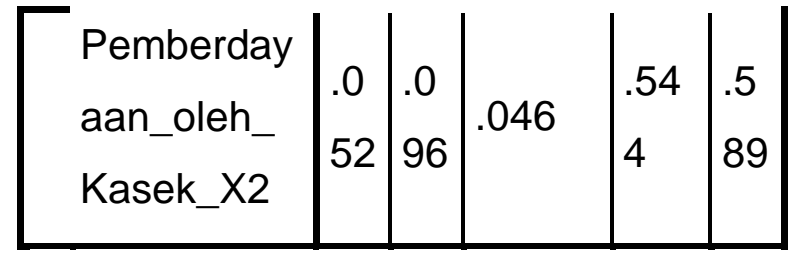

a. Dependent Variable:

Kepuasan_Kerja_Guru_Y

Berdasarkan tabel hasil uji $\mathrm{t}$ diperoleh bahwa nilai thitung variabel dukungan pengembangan karir dan pemberdayaan oleh kepala sekolah secara bersama-sama (simultan) memiliki nilai sebesar $p$-value $0,000<$ 0,05 artinya signifikan. Dengan demikian dukungan pengembangan karir dan pemberdayaan oleh kepala sekolah secara bersama-sama (simultan) berkontribusi terhadap kepuasan kerja guru.

Untuk mengetahui persamaan regresi dapat dilihat dari tabel di atas. Berdasarkan tabel tersebut menunjukkan persamaan regresi liniar ganda: $Y=5,543+0,862 X_{1}+$ $0,052 X_{2}$. Persamaan tersebut menyatakan bahwa setiap penambahan $X_{1}$ dan $X_{2}$ sebesar 1 maka akan meningkatkan $Y$ sebesar 0,862 dan 0,052 , artinya setiap peningkatan dukungan pengembangan karir dan pemberdayaan oleh kepala sekolah sebesar 1, akan meningkatkan kepuasan kerja guru sebesar 0,862 dan 0,052 .

Uji $F$ untuk menguji signifikan konstanta dan variabel dependen (kepuasan kerja guru). Dasar pengambilan keputusan yaitu dengan membandingkan $F$ hitung dengan nilai $F$ tabel sebagai berikut: Jika nilai signifikansi $<0,05$, maka Ho ditolak artinya koefisien regresi signifikan, dan sebaliknya.

Tabel 8: Signifikansi Kontribusi Variabel Dukungan Pengembangan Karir dan Pemberdayaan oleh Kepala Sekolah Secara Simultan terhadap Kepuasan Kerja Guru

\section{ANOVA $^{\mathrm{a}}$}

\begin{tabular}{|c|c|c|c|c|c|}
\hline Model & $\begin{array}{l}\text { Sum } \\
\text { of } \\
\text { Squ } \\
\text { ares }\end{array}$ & $\begin{array}{l}d \\
f\end{array}$ & $\begin{array}{l}\text { Me } \\
\text { an } \\
\text { Sq } \\
\text { uar } \\
\text { e }\end{array}$ & $F$ & $\begin{array}{l}\mathrm{Si} \\
\mathrm{g} .\end{array}$ \\
\hline $\begin{array}{l}\text { Regr } \\
\text { essio } \\
\mathrm{n} \\
\text { Resi } \\
\text { dual } \\
\text { Total }\end{array}$ & $\begin{array}{l}1951 \\
.628 \\
449 . \\
926 \\
2401 \\
.554\end{array}$ & $\begin{array}{l}5 \\
3\end{array}$ & $\begin{array}{l}975 \\
.81 \\
4 \\
8.4 \\
89\end{array}$ & $\begin{array}{l}114 \\
.94 \\
8\end{array}$ & $\begin{array}{l}.0 \\
00\end{array}$ \\
\hline
\end{tabular}


a. Dependent Variable:

Kepuasan_Kerja_Guru_Y

b. Predictors: (Constant),

Pemberdayaan_oleh_Kasek_X 2 ,

Dukungan_Pengembangan_Ka rir_X1

Berdasarkan tabel hasil uji anova atau $\mathrm{F}$ test didapat $\mathrm{F}_{\text {hitung }}$ sebesar 114,948 dan signifikansi $0,000<0,05$ sehingga $H_{\circ}$ ditolak artinya kontribusi dukungan pengembangan karir dan pemberdayaan oleh kepala sekolah secara simultan terhadap kepuasan kerja guru adalah signifikan.

Selanjutnya untuk mengetahui besaran kontribusi dukungan pengembangan karir dan pemberdayaan oleh kepala sekolah secara bersama-sama (simultan) terhadap kepuasan kerja guru dapat dilihat dari hasil perhitungan koefesien determinasi pada tabel dibawah ini:

Tabel 9: Besaran Kontribusi Variabel Dukungan Pengembangan Karir dan Pemberdayaan oleh Kepala Sekolah Secara Simultan terhadap Kepuasan Kerja Guru
Model Summary

\begin{tabular}{|c|c|c|c|c|}
\hline $\begin{array}{l}\text { Mo } \\
\text { del }\end{array}$ & $R$ & $\begin{array}{l}\text { R } \\
\text { Squa } \\
\text { re }\end{array}$ & \begin{tabular}{|l} 
Adju \\
sted \\
R \\
Squa \\
re
\end{tabular} & $\begin{array}{l}\text { Std. } \\
\text { Error of } \\
\text { the } \\
\text { Estimat } \\
\text { e }\end{array}$ \\
\hline 1 & $\begin{array}{l}.9 \\
01 \\
a\end{array}$ & .813 & .806 & 2.914 \\
\hline
\end{tabular}

a. Predictors: (Constant), Pemberdayaan_oleh_Kasek_ $\mathrm{X} 2$,

Dukungan_Pengembangan_K arir_X1

Dari tabel di atas terlihat bahwa $R$ Square sebesar 0,813 , hal ini berarti bahwa $0,813 \times 100 \%=$ $81,3 \%$ kepuasan kerja guru mendapat kontribusi dari variabel dukungan pengembangan karir dan pemberdayaan oleh kepala sekolah secara bersama-sama (simultan), sedangkan sisanya 18,7\% mendapat kontribusi dari faktor lain yang tidak diteliti.

\section{Pembahasan Hasil Penelitian}

Konsep yang dijadikan rujukan dalam membahas hasil penelitian ini terdiri dari dukungan pengembangan karir, pemberdayaan oleh kepala 
sekolah dan kepuasan kerja guru, dibahas sebagai berikut. Permasalahan yang ingin dijawab dalam penelitian ini adalah adakah kontribusi dukungan pengembangan karir terhadap kepuasan kerja guru. Secara empirik, hasil penelitian ini menginformasikan, bahwa terdapat kontribusi yang signifikan dukungan pengembangan karir terhadap kepuasan kerja guru. Menurut Notoatmodjo (2003:3), pengembangan sumber daya manusia (human resources development) itu sendiri terbagi dua, yaitu pengembangan makro dan pengembangan mikro. Pengembangan makro adalah "suatu proses peningkatan kualitas atau kemampuan manusia dalam rangka mencapai suatu tujan pembangunan bangsa. Proses peningkatan di sini mencakup

perencanaan, pengembangan, dan pengelolaan sumber daya manusia". Sedangkan pengembangan sumber daya manusia secara mikro adalah "suatu proses perencanaan pendidikan, pelatihan dan pengelolaan tenaga atau karyawan untuk mencapai suatu hasil optimal. hasil ini dapat berupa jasa maupun benda atau uang" (Notoatmodjo, 2003:4). Berikutnya
Notoatmodjo, masih dalam halaman yang sama, menambahkan "Dari batasan ini dapat disimpulkan bahwa proses pengembangan sumberdaya manusia itu terdiri dari perencanaan (planning), pendidikan dan pelatihan (education and training), dan pengelolaan (management)". Notoatmodjo (2003:9-12) juga memberikan pernyataan bahwa pengambangan sumber daya manusia sangat penting untuk dilakukan, serta terdapat beberapa faktor yang harus dipertimbangkan dalam pelaksanaannya, berikut pernyataannya.

Proses pengembangan sumber daya manusia adalah suatu conditio sine quanon, yang harus ada dan terjadi di suatu organisasi. Namun demikian dalam pelaksanaan pengembangan sumber daya manusia ini perlu mempertimbangkan faktor-faktor, baik dalam diri organisasi itu sendiri maupun dari luar organisasi yang bersangkutan (internal dan eksternal).

Namun demikian kepuasan kerja guru ini tidak hanya dikontribusii oleh dukungan pengembangan karir saja, ada faktor lain (epsilon), selain pemberdayaan oleh kepala sekolah, yang juga berkontribusi, yang tidak 
dikaji dalam penelitian ini. Dengan demikian, hasil penelitian ini mengindikasikan bahwa semakin bagus dukungan pengembangan karir yang dirasakan oleh guru, maka akan diikuti oleh semakin tingginya kepuasan kerja guru. Hal ini dapat diterangkan oleh persamaan regresi $y=6,846+0,894 X_{1}$. Dengan persamaan regresi tersebut dapat diinterpretasikan bahwa jika dukungan pengembangan karir $\left(X_{1}\right)$ dan kepuasan kerja guru $(\mathrm{Y})$ diukur dengan instrumen yang dikembangkan dalam penelitian ini, maka setiap perubahan skor dukungan pengembangan karir sebesar satu satuan dapat diestimasikan skor kepuasan kerja guru akan berubah 0,894 satuan pada arah yang sama.

Berdasarkan temuan empirik yang menunjukkan adanya kontribusi yang signifikan dukungan pengembangan karir terhadap kepuasan kerja guru, maka hasil penelitian ini memberikan beberapa informasi, di antaranya: (1) Kondisi dukungan pengembangan karir memberikan kontribusi yang berarti terhadap kepuasan kerja guru, (2) Salah satu cara untuk meningkatkan kepuasan kerja guru adalah dengan meningkatkan

dukungan pengembangan karir, serta (3) Kontribusi yang diberikan dari dukungan pengembangan karir terhadap kepuasan kerja guru adalah sebesar $81,2 \%$, sementara sisanya mendapat kontribusi dari variabel lain, selain variabel pemberdayaan oleh kepala sekolah, yang tidak dikaji dalam penelitian ini (epsilon).

Permasalahan berikutnya yang ingin dijawab dalam penelitian ini adalah adakah kontribusi pemberdayaan oleh kepala sekolah terhadap kepuasan kerja. Secara empirik, hasil penelitian ini menginformasikan, bahwa terdapat kontribusi yang signifikan pemberdayaan oleh kepala sekolah terhadap kepuasan kerja guru. Menurut Suhardan (2010:86), pemberdayaan merupakan suatu usaha untuk mempertinggi kecakapan guru dalam mengemban profesinya. Pemberdayaan merupakan suatu usaha agar guru memperoleh kewenangan mengajar sesuai dengan standar profesional. Dengan dilakukannya pemberdayaan oleh kepala sekolah terhadap guru diharapkan dapat mengembangkan kompetensi guru dalam melakukan pembelajaran, sehingga guru 
memperoleh kekuasaan mengajar, melakukan kegiatan belajar mengajar lebih kreatif dan berkembang sehingga dapat meningkatkan mutu pembelajaran.

Namun demikian kepuasan kerja guru ini tidak hanya dikontribusii oleh pemberdayaan oleh kepala sekolah saja, ada faktor lain (epsilon), selain dukungan pengembangan karir yang juga berkontribusi, yang tidak dikaji dalam penelitian ini. Dengan demikian, hasil penelitian ini mengindikasikan bahwa semakin bagus kondisi pemberdayaan oleh kepala sekolah, maka akan diikuti oleh semakin tingginya kepuasan kerja guru. Hal ini dapat diterangkan oleh persamaan regresi $Y=14,297+$ $0,752 X_{2}$. Dengan persamaan regresi tersebut dapat diinterpretasikan bahwa jika pemberdayaan oleh kepala sekolah $\left(\mathrm{X}_{2}\right)$ dan kepuasan kerja guru $(\mathrm{Y})$ diukur dengan instrumen yang dikembangkan dalam penelitian ini, maka setiap perubahan skor pemberdayaan oleh kepala sekolah sebesar satu satuan dapat diestimasikan skor kepuasan kerja guru akan berubah 0,752 satuan pada arah yang sama.
Berdasarkan temuan empirik yang menunjukkan adanya kontribusi yang signifikan pemberdayaan oleh kepala sekolah terhadap kepuasan kerja guru, maka hasil penelitian ini memberikan beberapa informasi, di antaranya: (1) Kondisi pemberdayaan oleh kepala sekolah memberikan kontribusi yang berarti terhadap kepuasan kerja guru, (2) Salah satu cara untuk meningkatkan kepuasan kerja guru adalah dengan meningkatkan pemberdayaan oleh kepala sekolah, serta (3) Kontribusi yang diberikan dari pemberdayaan oleh kepala sekolah terhadap kepuasan kerja guru adalah sebesar $43,6 \%$, sementara sisanya mendapat kontribusi dari variabel lain, selain variabel dukungan pengembangan karir, yang tidak dikaji dalam penelitian ini (epsilon).

Permasalahan terakhir yang ingin dijawab dalam penelitian ini adalah adakah kontribusi dukungan pengembangan karir dan pemberdayaan oleh kepala sekolah secara simultan terhadap kepuasan kerja guru. Secara empirik, hasil penelitian ini menginformasikan, bahwa terdapat kontribusi yang signifikan dukungan pengembangan karir dan pemberdayaan oleh kepala 
sekolah secara simultan terhadap kepuasan kerja guru. Namun demikian kepuasan kerja guru, selain dikontribusii oleh kedua variabel di atas, ada faktor lain (epsilon), yang juga berkontribusi, yang tidak dikaji dalam penelitian ini. Dengan demikian, hasil penelitian ini mengindikasikan bahwa semakin bagus kondisi dukungan pengembangan karir dan pemberdayaan oleh kepala sekolah secara simultan yang dirasakan oleh guru, maka akan diikuti oleh semakin tingginya kepuasan kerja guru. Hal ini dapat diterangkan oleh persamaan regresi $\hat{Y}=5,543+0,862 X_{1}+$ $0,052 X_{2}$.

Dengan persamaan regresi tersebut dapat diinterpretasikan bahwa jika dukungan pengembangan karir $\left(X_{1}\right)$, dan pemberdayaan oleh kepala sekolah $\left(\mathrm{X}_{2}\right)$ dan kepuasan kerja guru ( $\mathrm{Y})$ diukur dengan instrumen yang dikembangkan dalam penelitian ini, maka setiap perubahan skor dukungan pengembangan karir, dan pemberdayaan oleh kepala sekolah secara simultan sebesar satu satuan dapat diestimasikan skor kepuasan kerja guru akan berubah 0,862 dan 0,052 satuan pada arah yang sama.
Berdasarkan temuan empirik yang menunjukkan adanya kontribusi yang signifikan dukungan pengembangan karir dan pemberdayaan oleh kepala sekolah terhadap kepuasan kerja guru, maka hasil penelitian ini memberikan beberapa informasi, di antaranya: (1) Kondisi dukungan pengembangan karir dan pemberdayaan oleh kepala sekolah memberikan kontribusi yang berarti terhadap kepuasan kerja guru, (2) Salah satu cara untuk meningkatkan kepuasan kerja guru adalah dengan meningkatkan dukungan pengembangan karir dan pemberdayaan oleh kepala sekolah. (3) Kontribusi yang diberikan oleh dukungan pengembangan karir dan pemberdayaan oleh kepala sekolah secara bersama-sama (simultan) terhadap kepuasan kerja guru adalah sebesar $81,3 \%$, sementara sisanya mendapat kontribusi dari variabel lain, yang tidak dikaji dalam penelitian ini (epsilon).

\section{Kesimpulan}

Pertama, terdapat kontribusi yang positif dan signifikan dukungan pengembangan karir terhadap kepuasan kerja guru dengan besaran 
kontribusi $81,2 \%$, sedangkan sisanya $18,8 \%$ ditentukan oleh faktor lain. Kedua, terdapat kontribusi yang positif dan signifikan pemberdayaan oleh kepala sekolah terhadap kepuasan kerja guru dengan besaran kontribusi 43,6\%, sedangkan sisanya $56,4 \%$ ditentukan oleh faktor lain. Ketiga, terdapat kontribusi yang positif dan signifikan dukungan pengembangan karir dan pemberdayaan oleh kepala sekolah secara simultan terhadap kepuasan kerja guru dengan besaran kontribusi $81,2 \%$, sedangkan sisanya $18,8 \%$ ditentukan oleh faktor lain.

\section{DAFTAR PUSTAKA}

Adi, I.R. (2003). Pemberdayaan, Pengembangan Masyarakat dan Intervensi Komunitas. Jakarta: FEUI.

Armstrong, Michael. (2002). Encyclopedia Human Resource Management. New Delhi : Crest Publishing House.

Bernadin, H.John \& Joyce E.A. Russell., (1993), Human Resource Management, International Edition, Singapura: Mc.GrawHill, Inc

Cascio, Wayne F. (2002). Managing Human Resources, Productivity, Quality of Work Life, Profits. Fourth Ed, New York: Mac Graw Hill.
Castetter, William B. (2002). The Human Resource Funtion in Educational Administration. Sixth Edition. New JerseyColumbus, Ohio: Prentice Hall

Durbin, Andrew J.

(2000). Essential of Management. Dallas: South Western Pub., Co.

Eka, R. (2007). Kondisi Pemerataan Pendidikan di Indonesia. [Online]. Tersedia: http://eduarticles.com. [26 Desember 2010].

Feildman, Daniell C. and Hugh J. Arnold. (1993), Managing Individual and Group Behaviour in Organization. New York: McGiraw-Hill.

Flippo, Edwin B. (2001), Manajemen Personalia, Jakarta: Erlangga.

Gary, Dessler, (1996), Manajemen Sumber Daya Manusia, terjemahan Benyamin Molan. Jakarta: Prenhalindo.

Gibson,James L.,(2004). Organization, Behavior, Structure and Prosess. Organisasi, Perilaku,Struktur dan Proses, Jakarta: Binarupa Aksara

Goble Frank G. (2001). Mazhab kerja : Psikologi Humanistik Abraham Maslow,terjemahan A. Supratiknya. Yogyakarta : Kanisius.

Lawler, E.E and L.K Porter. (1967), The Effect of Performance, Industrial Relation.

McKenna. E \& Beech. (2000). Manajemen Sumber Daya Manusia. Yogyakarta: Andi.

Mondy, R. Wayne, Robert M. Noe, (2006). Human Resources 
Management. Allyn and Bacon Inc, USA.

Notoatmodjo, Soekidjo. (2003). Pengembangan Sumber Daya Manusia. Jakarta: Penerbit Rineka Cipta.

Porter, L. W., R. M. Steers, R. T. Mowday \& V Boulian, (1984), "Organizational Commitment, Job satisfaction, and Turnover among Psychiatric Technicians". Journal of Applied Psychology, October 1984, pp. 603-09.

Ralph, Wenrich, et.al. (2001), Administration Vocational Education, American Tchnical Publisher, Inc.

Robbins, P. Stephen. (2008). Perilaku Organisasi. Jakarta: Prenhallindo.

Sholeh, Muhammad, M.Pd. (2008). Peran Kepala Sekolah dalam Pemberdayaan [Online]. Guru. http://drssuharto. wordpress.com/2008/03/04/

Siagian, P. Sondang. (2005). Manajemen Sumber Daya Manusia. Jakarta: Bumi Aksara.

Snell, SA., (2002). Diagnosis kinerja : Mengenali Penyebabpenyebab Kinerja Buruh. Jakarta: Media Komputindo.

Suhardan, Dadang. (2010). Supervisi Profesional: Layanan dalam Meningkatkan Mutu Pembelajran di Era Otonomi Daerah. Bandung: Alfabeta.

Sutisna, Orteng (2002). Administrasi Pendidikan: Dasar Teoritis Untuk Praktek Profesional. Bandung: Angkasa.
Usmara, Anwar. (2003). Paradigma Baru Sumber Daya Manusia. Yogyakarta: Amara Books.

Wexley, Kenneth N dan Gary Yulk. (1999).

Organizational Behavior and Personnel Psychology. Homewood Illinois: Richard D, Irwin, Ltd,. 